\title{
LABORATORY ANALYSIS OF THE RAINWATER RUNOFF FROM AN URBANIZED AREA
}

\author{
${ }^{1}$ Ivana MARKO*, ${ }^{2}$ Réka CSICSAIOVÁ, ${ }^{3}$ Jaroslav HRUDKA \\ ${ }^{4}$ Ivona ŠKULTÉTYOVÁ, ${ }^{5}$ Štefan STANKO, ${ }^{6}$ Paula BRANDEBUROVÁ \\ ${ }^{1-5}$ Department of Sanitary and Environmental Engineering, Faculty of Civil Engineering \\ The Slovak University of Technology in Bratislava, Radlinského 11, 81005 Bratislava \\ Slovakia, e-mail: ${ }^{1}$ ivana.marko@stuba.sk, ${ }^{2}$ reka.csicsaiova@stuba.sk, \\ 3jaroslav.hrudka@stuba.sk, ${ }^{4}$ ivona.skulteytova@stuba.sk, ${ }^{5}$ stefan.stanko@stuba.sk \\ ${ }^{6}$ Department of Environmental Engineering, Faculty of Chemical and Food Technology \\ The Slovak University of Technology in Bratislava, Radlinskeho 9, 81237 Bratislava \\ Slovakia, e-mail: ${ }^{6}$ paula.brandeburov@stuba.sk
}

Received 30 December 2019; accepted 14 April 2020

\begin{abstract}
The aims of the research are to focus on the analysis of qualitative parameters of surface runoff from the urbanized area (parking, roadways); subsequently, to compare the measured concentration with the recommendations of Danish and Slovak standards. Rainwater sampling carried out at several sites in Serbia and Slovakia. In the analysis were monitoring, the qualitative parameters as $\mathrm{pH}$ value, water conductivity, chemical oxygen demand, and heavy metals. The results show the presence of copper, zinc, lead, aluminum, cadmium, chromium and nickel. The concentration of these parameters was several times higher than the allowed limit values. Based on these results, it is necessary to design measures to ensure surface runoff before infiltration.
\end{abstract}

Keywords: Heavy metals, Rainwater, Surface runoff, Qualitative parameters

\section{Introduction}

The 20th century is characterized by a mass migration and the development of urbanization and infrastructure. It is a natural process, which brings with it specific problems that are changing the spatial structure of the city: more paved and impermeable areas and least permeable surface [1]. The accelerated development of urbanization and the support of towns to build artificial landscape features lead to lasting changes in the city, which may have a negative impact on the environment.

\footnotetext{
${ }^{*}$ Corresponding Author
} 
The development of a paved surface can cause changes in the hydrological characteristics of the area [2], [3]. The increase of the impermeable surface can affect the penetration of atmospheric water into the soil horizon, which in turn leads to a decrease in the yield of groundwater resources. Nowadays, it is a challenge to assure the drinking water for the population in some countries on the point of view of quality and quantity. The main priority of water managers is the great cities, where it is necessary to satisfy the growing demand for drinking water.

All over the world, there are more than $500,000 \mathrm{~km}^{2}$ of paved areas [4]. The impermeable surface does not support the natural infiltration of rainwater and negatively affect the microclimate of the city [4]. Artificial landscape features like roads, parking lots, streets, and other paved areas, when are correctly used, can provide an alternative source of water through a rainwater system [5]. Rainwater collection is one of the best available methods to create a sustainable water cycle in a city. An efficient way of managing rainwater could reduce the costs of transport and treatment of drinking water and wastewater, and in particular, regulate floods in the city.

The traditional method of rainwater management from urbanized areas is based on the principle of the fastest rainwater runoff from paved areas [6]. However, it has proved to be not the most appropriate solution. The development of urbanization and the effects of climate change often load the sewerage system and subsequent flooding of certain parts of the city. Municipal authorities are currently striving to make use of nature-friendly measures that use the foundations of Blue-Green infrastructure [7]. Blue-Green infrastructure elements are natural-friendly measures like wetlands, green roofs, or green walls that provide rainwater infiltration and have a beneficial effect on the microclimate of the city [8].

This research focused on capturing the first rainwater flush from paved areas in Slovakia and Serbia. Interesting localities are in Bratislava, Slovak Republic, and village Hložany, Republic of Serbia. The analysis was focusing on the evaluation of qualitative parameters of surface runoff from urbanized areas. The study was divided into two parts. The first part was focus to the evaluation of the $\mathrm{pH}$ and conductivity of surface runoff. In the second part, the heavy metals were measured in urban stormwater. The evaluation of the measured values was by the Regulation of the Government of the Slovak Republic No. 269/2010 [9] and the Danish standard for surface water [10].

\section{Characteristic of surface runoff}

\subsection{Qualitative parameters of rainwater}

The chemical form of the rain mostly depends on composition and air pollution in the lower and middle parts of the atmosphere, and local condition (industry, mountain) [11]. The most polluted rainwater occurs in the region of large industrial sites, especially around the chemical plant and at least in mountain areas. Furthermore, the composition of the rainwater depends on the type of paved area on which it will fall. Usual rain contains the following parameters: chlorides, sulfates, nitrates, potassium, calcium, and magnesium in concentrations up to $10.0 \mathrm{mg} \cdot \mathrm{l}^{-1},[11]$. In industrial areas, 
there is an increased proportion of sulfur, nitrogen, ammonia, traces of salts, dust, and bacteria.

These gasses are giving the water a slightly acidic character and changing the $\mathrm{pH}$ value. In areas with unpolluted atmospheres, e.g. mountain areas, the $\mathrm{pH}$ of rainwater range between 5.5 and 6.0, while in industrial areas, it reaches a value of about 3.5, [11]. The $\mathrm{pH}$ value is the most crucial parameter in rainwater, which significantly affects the solubility and transfer of heavy metals from an urbanized area to groundwater and the decomposition of salts present in the water.

\subsection{Surface runoff}

As the intensification of urbanization, a new source of urban pollution was identified surface runoff. It is a complex source, which depends on several parameters: the duration, and intensity of precipitation, the weather in the previous period, the surface characteristics of land use, etc. [12]. Rainwater runoff that arises in impermeable areas plays a significant role in the drainage of the urbanized area. In designing rainwater management measures and facilities correctly, it is essential to know the qualitative parameters of surface runoff and the total amount of rainwater, which falls in a paved area. Surface runoff caused by rainfall is the primary transport medium of pollutants that can cause significant environmental impacts [6]. Depending on local conditions (traffic, industry, etc.), the nature of the pollutant changes, and so surface runoff may contain a substance that is unwanted for an environment. The quality of rainwater from impermeable surfaces depends on the materials used for the construction of paved areas [13], the geometry [14], and the length of the previous rainfall-free period.

Under normal conditions, heavy metals like $\mathrm{Cd}, \mathrm{Cu}, \mathrm{Ni}, \mathrm{Z}, \mathrm{Zn}$ in concentrations of about $1.0 \mathrm{mg} . \mathrm{l}^{-1}$ are present in surface runoff [11]. In the long-period, without a rainy season, the amount of pollutants in the surface runoff increases significantly. The concentration of undesirable pollutants may exceed the limit values several times. The highest amount of pollutants in the surface runoff accumulates in the initial phase, at the beginning of the precipitation event [15].

The chemical composition of the surface runoff mainly depends on the types of impermeable surfaces, whether it is a roof [16], [17], a parking lot, a roadway [15], or another paved area. The type of roadways can also influence the quality of surface runoff. In a motorway, highway, or class II roads have discovered different types of pollutants [15]. The surface runoff from the car parks and roadway mostly contain substances from vehicles are as petroleum substances, certain toxic substances, and organic compounds. In rainfall, from the roof was found an increased concentration of heavy metals [18], [19], or inert roof sediment (e.g., dust and feces in animals) [20].

\section{Methodic of research}

\subsection{Study area}

The research aimed to select and compare different locations in urbanized areas in the Slovak Republic and the Republic of Serbia. The choice of regions of interest for 
this study affects several factors: availability of sampling, local conditions, types of impermeable surface, and hydrological conditions (intensity and duration of rainfall). The selected area of interest in Slovakia was in the cadastral area of Bratislava historical town, and in Serbia, the village Hložany. The region of Bratislava is characterizing by a large number of impermeable surfaces, and dense traffic (urban transport, motor cars). The area of Hložany stands out for its agriculture activities.

\subsection{Sampling}

The research was focused on capturing the first rainwater runoff from roadway and car parking due to the assumption of the highest amount of pollutants in surface runoff. Table I shows the basics information of the captured samples as capture date, location, GPS coordinates, and type of paved surface.

Table I

Characteristic of rainwater sampling

\begin{tabular}{|c|c|c|c|c|}
\hline Samples & Data & Place & Function & Material \\
\hline 1 & 25.03 .2019 & $\begin{array}{c}\text { Maršala Tita Street - Hložany } \\
\text { (Serbia) }\end{array}$ & roadway & asphalt \\
\hline 2 & 25.03.2019 & $\begin{array}{l}\text { Novosadcki Street - Hložany } \\
\text { (Serbia) }\end{array}$ & roadway & asphalt \\
\hline 3 & 22.04 .2019 & $\begin{array}{c}\text { Maršala Tita Street- Hložany } \\
\text { (Serbia) }\end{array}$ & roadway & asphalt \\
\hline 4 & 22.04 .2019 & $\begin{array}{c}\text { Novosadcki Street - Hložany } \\
\text { (Serbia) }\end{array}$ & roadway & asphalt \\
\hline 5 & 01.07 .2019 & Krížna Street (Bratislava) & junction & asphalt \\
\hline 6 & 24.08 .2019 & Blumentálska Street (Bratislava) & car parking & $\begin{array}{c}\text { concrete } \\
\text { blocks }\end{array}$ \\
\hline 7 & 24.08 .2019 & Krížna Street (Bratislava) & roadway & asphalt \\
\hline 8 & 06.09 .2019 & Krížna Street (Bratislava) & roadway & asphalt \\
\hline 9 & 09.09 .2019 & Krížna Street (Bratislava) & roadway & asphalt \\
\hline
\end{tabular}

Sampling was during the period of winter, spring, and summer from March to September. First rainwater runoff was forward of the rain inlet. Each harvesting rainwater contained information from the collection point as it is shown in Table I. Altogether there were nine samples, four from Serbia from Maršala Tita and Novosadcki Street and five from Bratislava, Krížna and Blumentálska Street. Most of the samples were harvested from the roadway; just one was from the junction (Krížna and Legionárska Street). The paved surface from which was catching the samples built from asphalt and concrete blocks.

\subsection{Laboratory analysis}

The research focuses on the evaluation of qualitative parameters in captured rainwater in Slovakia - Bratislava, and Serbia - village Hložany, like $\mathrm{pH}$ value, the conductivity of water, and heavy metals. 
The first laboratory analyses of collected rainwater samples were in the Department of Sanitary and Environmental Engineering, Faculty of Civil Engineering, The Slovak Technical University in Bratislava. In this part of the analysis, $\mathrm{pH}$ value, and the conductivity of surface runoff were determined. The device HQD Portable Meters form the company HACH was used to measure the $\mathrm{pH}$ value of the rainwater [21].

The second analysis was realized at the Department of Environmental Engineering, the Faculty of Chemical and Food Technology, in The Slovak University of Technology in Bratislava. In this analysis were monitored the heavy metals as copper, zinc, lead, aluminum, cadmium, chromium and nickel.

For the evaluation of the measured parameters of the first rainwater runoff from the selected areas were taken in Slovakia and Serbia, the limit values for surface water quality according to the Regulation of the Government of the Slovak Republic No. 269/2010 [9] establishing requirements for achieving good water status and Danish standards for surface water quality [10] was used. The Danish criteria are aligning with the recommendations of the European Union, and it is one of the few countries that deal with the quality and impact of surface runoff on the environment. According to the Danish legislation, stormwater runoff is considered to be wastewater, and therefore its needs to be treated before infiltration to the soil [10].

\section{Result and discussion}

\section{1. $p H$ and conductivity}

The first part of the research has focused on the analysis of parameters as $\mathrm{pH}$ value and conductivity of rainwater from surface runoff. Table II presented the measured results from the first part of the study. In Table II the measurement of $\mathrm{pH}$ values and conductivity of rainwater runoff from the selected urbanized area are listed.

The limit value of $\mathrm{pH}$ is from 6.0 to $8.5(9.0)$, and of conductivity is $110 \mathrm{mS} \cdot \mathrm{m}^{-1}$.

\section{Table II}

The measured values of $\mathrm{pH}$ and conductivity of surface runoff

\begin{tabular}{|c|l|c|c|}
\hline Samples & \multicolumn{1}{|c|}{ Place } & $\begin{array}{c}\mathrm{pH} \text { value } \\
{[-]}\end{array}$ & $\begin{array}{c}\text { Conductivity } \\
{\left[\mathrm{mS.m}^{-1}\right]}\end{array}$ \\
\hline 1 & Maršala Tita Street - Hložany (Serbia) & 8.33 & 19.8 \\
2 & Novosadcki Street - Hložany (Serbia) & 9.09 & 14.41 \\
3 & Maršala Tita Street- Hložany (Serbia) & 8.26 & 18.01 \\
4 & Novosadcki Street - Hložany (Serbia) & 8.17 & 2.01 \\
5 & Krížna Street (Bratislava) & 7.69 & 21.21 \\
6 & Blumentálska Street (Bratislava) & 7.06 & 13.31 \\
7 & Krížna Street (Bratislava) & 7.09 & 12.42 \\
8 & Krížna Street (Bratislava) & 7.56 & 13.58 \\
9 & Krížna Street (Bratislava) & 7.73 & 17.86 \\
\hline
\end{tabular}

Based on data in Table II, the $\mathrm{pH}$ values of the collected rainwater ranged from 7.06 to 9.09. In sample No. 6 - Krížna Street (7.06) was measured the lowest $\mathrm{pH}$ and the 
highest at sample No. 2. - Novosadcki Street (9.09). Increased pH could be caused by traffic, the season, or even the amount of fallen rainwater. The measured concentrations of conductivity of stormwater ranged from $2.01 \mathrm{mS} . \mathrm{m}^{-1}$ to $21.21 \mathrm{mS} . \mathrm{m}^{-1}$. In sample No. 5 - Krížna Street has measured the highest value $-21.21 \mathrm{mS} . \mathrm{m}^{-1}$, and the lowest $2.01 \mathrm{mS} . \mathrm{m}^{-1}$ sample No. 4 - Novosadcki Street.

Fig. 1 represents the measured data of the first analysis. The horizontal line on the graph represents the limit value of $\mathrm{pH}$ (8.5) for surface water, set by the Government Regulation in Slovak Republic No. 269/2010 [9]. The vertical rectangles in Fig. 1 represent the measured $\mathrm{pH}$ values in the surface runoff. Based on the results shown in Fig. 1 it can be concluded that only one exceeds the limit value, sample No. 2, (9.09). The other samples analyses do not exceed the limit value; they are below the limit.

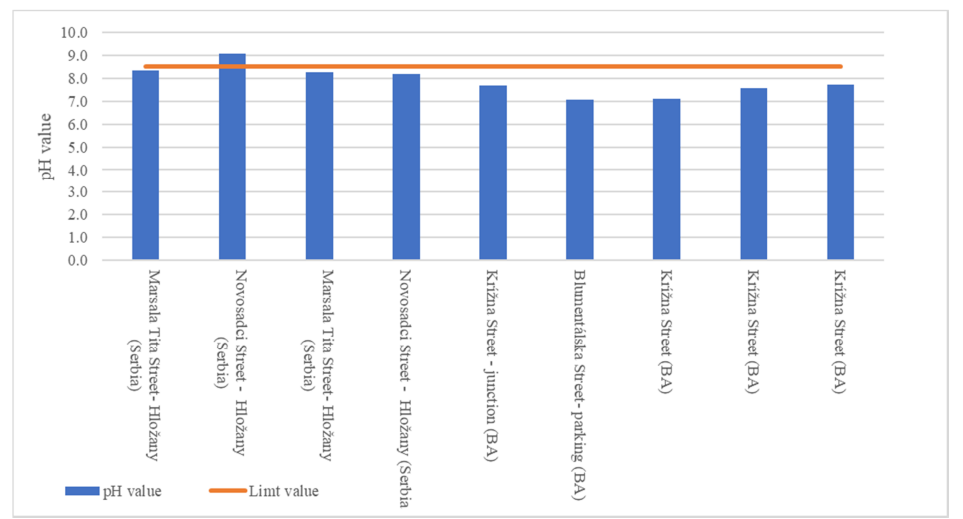

Fig. 1. The measured $\mathrm{pH}$ values of the collected rainwater samples from the paved surface in Bratislava and Hložany

Fig. 2 shows the measured conductivity values of the surface runoff captured from different locations. The vertical rectangles are presenting the measured concentration of conductivity in surface runoff, and the horizontal line, the limit value stated by Government Regulation, Slovak Republic No. 269/2010 [9]. According to regulation, the conductivity of surface water should not exceed $110 \mathrm{mS} . \mathrm{m}^{-1}$. Based on the requirement, all samples meet the limit values.

\subsection{Heavy metals}

The second part of the research was focused on the analysis of heavy metals as zinc, copper, nickel, aluminum, cadmium, lead, and chromium in rainwater runoff from an urbanized area. Table III shows the concentrations of detected heavy metals.

Evaluation of the results shown in Table III was according to the Danish criteria for groundwater quality [10]. In Slovakia, there is no regulation of technical standards, which sets limit values for surface runoff. 


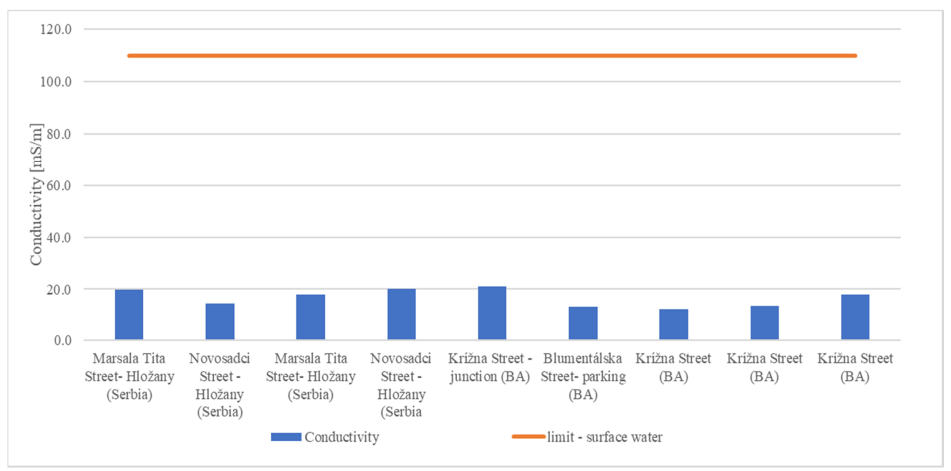

Fig. 2. The measured conductivity of the collected rainwater samples from the paved surface in Bratislava and Hložany

Table III

The measured concentration of heavy metals in surface runoff from the selected area

\begin{tabular}{|c|c|c|c|c|c|c|c|c|}
\hline No. & Place & $\mathrm{Zn}$ & $\mathrm{Cu}$ & $\mathrm{Ni}$ & $\mathrm{Al}$ & $\mathrm{Cd}$ & $\mathrm{Pb}$ & $\mathrm{Cr}$ \\
\hline & Limit Value $\left[\mathrm{mg} . \mathrm{l}^{-1}\right]$ & 0.0084 & 0.002 & 0.034 & - & 0.045 & 0.0028 & - \\
\hline 1 & $\begin{array}{l}\text { Marsala Tita Street- } \\
\text { Hložany (Serbia) }\end{array}$ & - & 0.018 & 0.045 & 0.03 & - & 0.099 & 0.012 \\
\hline 2 & $\begin{array}{l}\text { Novosadci Street - } \\
\text { Hložany (Serbia) }\end{array}$ & - & 0.008 & 0.029 & 0.058 & - & 0.103 & 0.011 \\
\hline 3 & $\begin{array}{l}\text { Marsala Tita Street- } \\
\text { Hložany (Serbia) }\end{array}$ & - & 0.01 & 0.038 & 0.02 & - & 0.107 & 0.011 \\
\hline 4 & $\begin{array}{l}\text { Novosadci Street - } \\
\text { Hložany (Serbia }\end{array}$ & 0.023 & 0.008 & 0.042 & 0.03 & - & 0.095 & 0.011 \\
\hline 5 & $\begin{array}{c}\text { Krížna Street - } \\
\text { junction (Bratislava) }\end{array}$ & 0.281 & 0.216 & 0.251 & 0.059 & - & 0.11 & 0.014 \\
\hline 6 & $\begin{array}{l}\text { Blumentálska Street- } \\
\text { parking (Bratislava) }\end{array}$ & 0.18 & 0.125 & 0.112 & 0.022 & 0.02 & 0.113 & 0.016 \\
\hline 7 & $\begin{array}{c}\text { Krížna Street } \\
\text { (Bratislava) }\end{array}$ & 0.158 & 0.15 & 0.218 & 0.023 & - & 0.116 & 0.013 \\
\hline 8 & $\begin{array}{l}\text { Krížna Street } \\
\text { (Bratislava) }\end{array}$ & 0.084 & 0.064 & 0.083 & 0.007 & 0.009 & 0.095 & 0.013 \\
\hline 9 & $\begin{array}{l}\text { Krížna Street } \\
\text { (Bratislava) }\end{array}$ & 0.082 & 0.06 & 0.108 & 0.005 & 0.022 & 0.109 & 0.014 \\
\hline
\end{tabular}

Based on the values set by the Danish standard, almost all samples exceed the limit concentration of heavy metals, except the $\mathrm{Al}$ and $\mathrm{Cr}$ do not have a limit defined. In some samples, it was not possible to measure metal concentrations, zinc in samples numbers one to three, and cadmium in samples one to five, and seven. According to the result listed in Table III, the concentration of heavy metal varies from $\left.0.008 \mathrm{mg}^{-1} \mathrm{l}^{-1} \mathrm{Cu}\right)$ to $0.281 \mathrm{mg} . \mathrm{l}^{-1}(\mathrm{Zn})$. The average concentration of total zinc was $0.135 \mathrm{mg} \cdot \mathrm{l}^{-1}$, for the cupper $0.073 \mathrm{mg} . \mathrm{l}^{-1}$, for the nickel $0.103 \mathrm{mg} . \mathrm{l}^{-1}$, for aluminum $0.028 \mathrm{mg} . \mathrm{l}^{-1}$, for the cadmium $0.017 \mathrm{mg} . \mathrm{l}^{-1}$, for the lead $0.105 \mathrm{mg} . \mathrm{l}^{-1}$, and for the chromium $0.013 \mathrm{mg} . \mathrm{l}^{-1}$. The graphical representation of the results in Table III is in Fig. 3.

Pollack Periodica 15, 2020, 3 


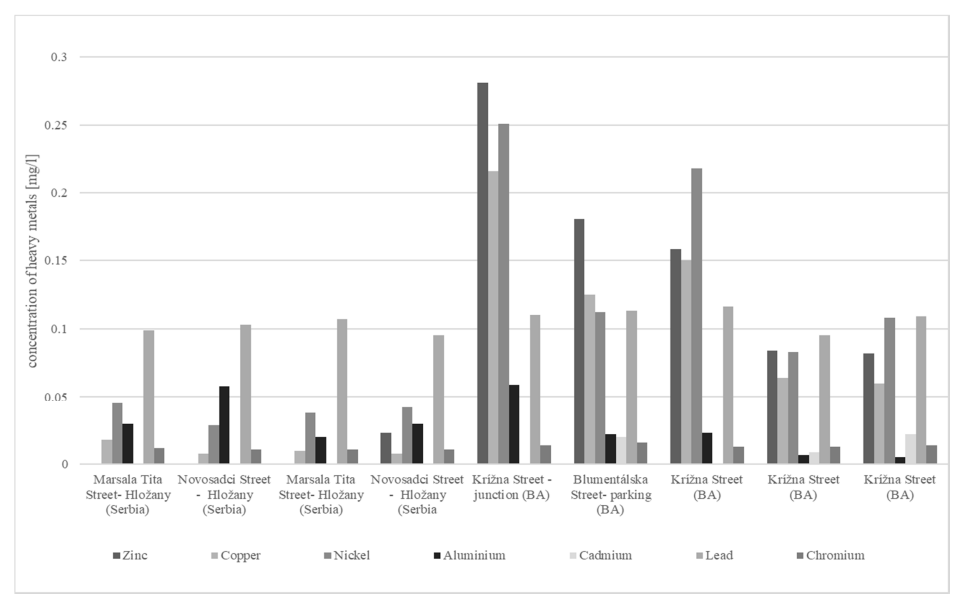

Fig. 3. The measured concentration of heavy metals in surface runoff from the selected area in Bratislava and Hložany

The heavy metals concentrations of all harvesting rainwater are in Fig. 3. On the graph, it can see a significant difference between the samples captured in different periods. In the samples taken in March, were measured lower metal concentrations (sample No. 1 to sample No. 4). As the graph shows, the highest detected level was in the samples from the summer period in July and August. Samples No. 8 and No. 9 was harvesting in September. In these samples lowest concentration are measured.

Sample No. 5 harvesting from Krížna Street had a strikingly higher level of heavy metals than others. High concentrations in sample No. 5 are likely caused by a long period without a rainy season, a place where it was catch sample, and by higher frenetic of traffic. In rainwater catching in Serbia was measured the lowest concentration. The season period and different types of traffic can cause a lower level of metals in surface runoff.

Fig. 4 shows the concentrations of a) zinc and b) copper. Each graph represents the measured concentrations of the detected parameter and the limit value set by the Danish standards. The horizontal line in the figure represents the limit value, and the vertical bars represent the measured concentration.

In analyzing zinc in the first four samples, it was not possible to measure the concentration (Fig. 4a). The highest detected level of zinc was $0.281 \mathrm{mg} \cdot \mathrm{l}^{-1}$ (sample No. 5). The lowest measured concentration of cooper was in samples No. 1 to No. 4 catching in Serbia (Fig. 4b). In sample No. 5 its reached value 0.216 mg. $1^{-1}$.

The concentration nickel and lead are shown in Fig. 5. In evaluating the concentration of nickel, just sample No. 2, do not have exceeded the limit. In the sample No. 5 and No. 7 were detected - the increased values (Fig. 5a). The measured concentration of lead in each sample exceeded the limit value several times. The concentration of lead in harvesting samples was approximately the same; it ranges from $0.095 \mathrm{mg} .1^{-1}$ to $0.113 \mathrm{mg} . \mathrm{l}^{-1}$ (Fig. 5 b). 


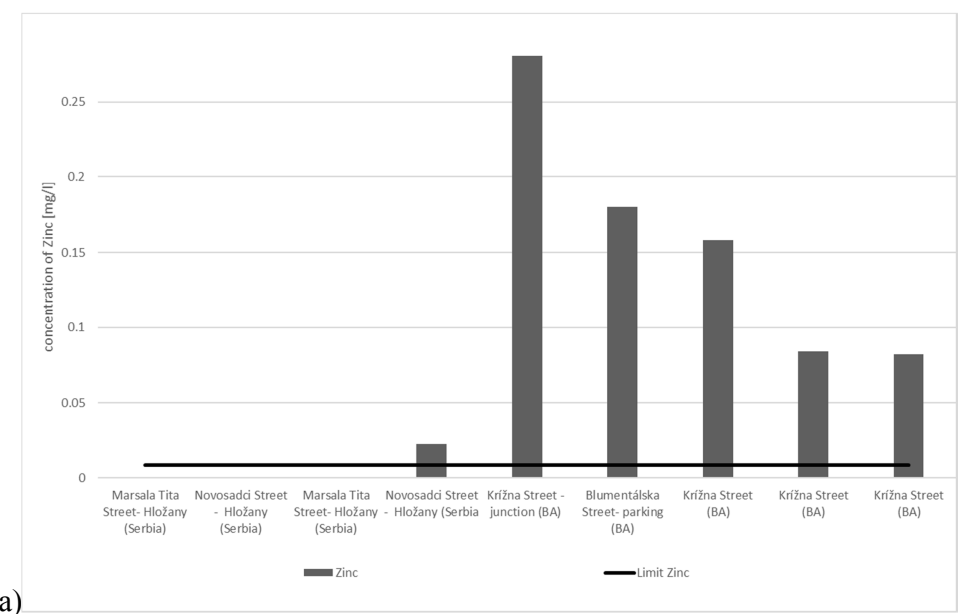

a)

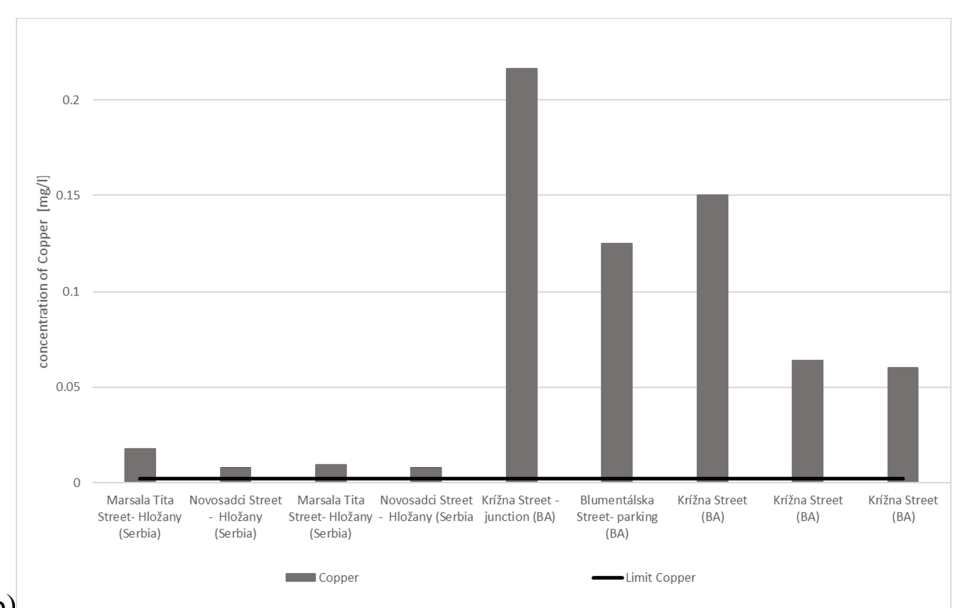

Fig. 4. The measured concentration of heavy metals a) zinc and b) cupper in surface runoff from the selected area in Bratislava and Hložany

\section{Conclusion}

This work was focusing on sampling and analyzing the first flush from an urbanized area. The reason for this research is firstly due to the possibility of infiltration water from surface runoff into the soil horizon. Another reason is the possibility of the occurrence of various pollutants on paved surfaces, which, if soaked into the soil, can cause groundwater contamination. The capturing of rainwater runoff was from roadways and car parks in Slovakia - Bratislava, and Serbia - Hložany. The analysis focuses on the evaluation of indicators as water reaction, $\mathrm{pH}$, conductivity, and heavy metals. 


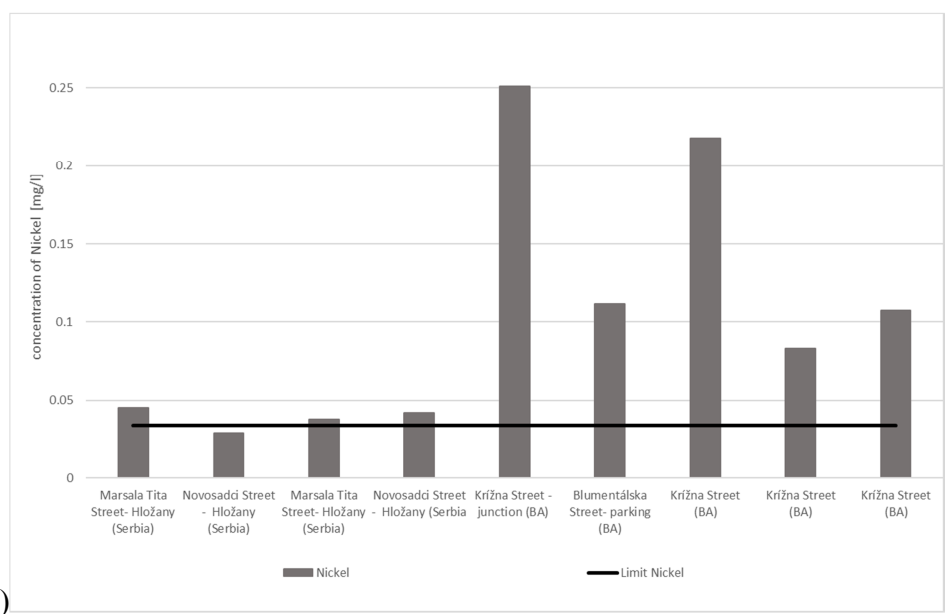

a)

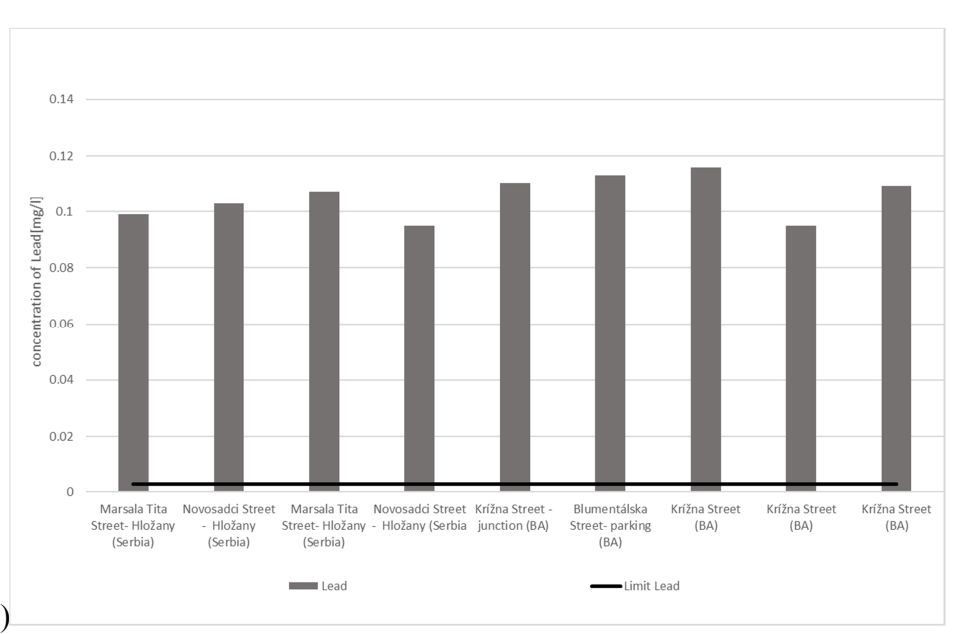

Fig. 5. The measured concentration of heavy metals a) nickel and b) lead in surface runoff from the selected area in Bratislava and Hložany

Based on the presented results, it can be concluded that not all rainwater samples met the permitted limit values. At the evaluated $\mathrm{pH}$, one exceeded the approved values, sample No. 2. In the case of rainwater conductivity, all samples are up to the limit. In the analysis of heavy metals, most samples exceed the limit value several times. The highest concentration was measured in sample No. 5. As it can be seen in the previous results stormwater is the most polluted after dry season. This statement can be stated based on samples collected in the summer period. In these samples was detected the higher concentration of metals than in samples from March. The increased level of heavy metals can also be affected by traffic; for example, sample No. 6 captured on Krížna Street, where the traffic intensity (passenger cars, urban transport) is increasing, and No. 7, that was from Blumentálska Street (cars). A change in samples from asphalt 
and concrete based on surface type is not relevant; the concentration was approximately equal.

According to the presented results, it can be a state that rainwater infiltration from the roadway and car parks is not the most appropriate solution. This rainwater is considered inappropriate and should undergo a purification process before soakage into the soil. For the future, it is necessary to propose measures to ensure that surface runoff is treated before infiltration. There are many opportunities for using the green land with Low Impact Development (LID) application (green roof, rain garden, bioretention cells, permeable concrete). Applying LID can reduce the runoff of sites and control pollution.

The research on this topic - laboratory analysis of the rainwater runoff from an urbanized area will continue with a focus on new urbanized areas and different paved surfaces.

\section{Acknowledgments}

This work is supported by 'Mladý výskumník' STU grant under the ADOHODOV acronym, funded by the Rectors office of the STU in Bratislava, (from March 2019 to December 2019), the Scientific Grant Agency of the Ministry of Education, Youth and Sports of the Slovak Republic and the Slovak Academy of Sciences within the project VEGA 1/0574/19, co-funded by the European Regional Development Fund and by the Slovak Research and Development Agency under the contract No. APVV-18-0203.

\section{Open Access statement}

This is an open-access article distributed under the terms of the Creative Commons Attribution-NonCommercial 4.0 International License (https:/creativecommons.org/ licenses/by-nc/4.0/), which permits unrestricted use, distribution, and reproduction in any medium for non-commercial purposes, provided the original author and source are credited, a link to the CC License is provided, and changes - if any - are indicated.

\section{References}

[1] Niyogi D., Lei M., Kishtawal C., Schmid P., Shepherd M. Urbanization impacts on the summer heavy rainfall climatology over the eastern United States, Earth Interactions, Vol. 21, No. 5, 2017, pages 1-17.

[2] Gao B., Gao L., Xu D., Zhang M., Qu X., Li Y. A novel method for evaluating the potential release of trace metals associated with rainfall leaching/runoff from urban soils, Science of the Total Environment, Vol. 664, 2019, pp. 37-44.

[3] Cao Q., Yu D. Y., Georgescu M., Wu J. G., Wang W. Impacts of future urban expansion on summer climate and heat-related human health in eastern China, Environment International, Vol. 112, 2018, pp. 134-146.

[4] Angrill S., Petit-Boix A., Morales-Pinzón T., Josa A., Rieradevall J., Gabarrell X. Urban rainwater runoff quantity and quality - A potential endogenous resource in cities, Journal of Environmental Management, Vol. 189, 2017, pp. 14-21. 
[5] Fletcher T. D., Deletic A., Mitchell V. G., Hatt B. E. Reuse of urban runoff in Australia: A review of recent advances and remaining challenges, Journal of Environmental Quality, Vol. 37, No. 5, 2008, pp. 116-127.

[6] Urcikán P., Rusnák D. Sewerage and wastewater treatment: Sewerage I. Design of sewerage networks, (in Slovak) Bratislava, The Slovak University of Technology in Bratislava, 2011.

[7] Ghafrani Z., Sposito V., Faggani R. A comprehensive review of blue-green infrastructure concepts, International Journal of Environment and Sustainability, Vol. 6, No. 1, 2017, pp. 15-36.

[8] Davis A. P. Green engineering principles promote low-impact development, Environmental Science \& Technology, Vol. 39, No. 16, 2005, pp. 338A-344A.

[9] Regulation of the Government of the Slovak Republic No. 269/2010, Laying down requirements for achieving good water status, (in Slovak) 2010.

[10] Ministry of Environment and Food of Denmark, Departmental Order Concerning Establishment of Environmental Goals for Streams, Lakes, Transition Waters, Coastal Waters, and Groundwater; Bek. No. 1070 of 09/09/2015, Ministry of Environment, and Food of Denmark, Copenhagen, Denmark, 2015.

[11] Pitterm. P. Hydrochemie 4, updated edition, Prague, Faculty of Chemical Technology, Prague, (in Czech) 2009.

[12] Li J., Jiang C., Lei T., Li Y. Experimental study and simulation of water quality purification of urban surface runoff using non-vegetated bioswales, Ecological Engineering, Vol. 95, 2016, pp. 706-713.

[13] Norman M., Shafri H. Z. M., Mansor S. B., Yusuf B. Review of remote sensing and geospatial technologies in estimating rooftop rainwater harvesting (RRWH) quality, International Soil and Water Conservation Research, Vol. 7, No. 3, 2019, pp. 266-274.

[14] Gikas G. D., Tsihrintzis V., A., Assessment of water quality of first-flush roof runoff and harvested rainwater, Journal of Hydrology, Vol. 466-467, 2012, pp. 115-126.

[15] Lee J., Kim H., Kim Y., Han M. Y. Characteristics of the event mean concentration (EMC) from rainfall-runoff on an urban highway, Environmental Pollution, Vol. 159, No. 4, 2011, pp. 884-888.

[16] Horvát A. Roof runoff quality and reduction possibility of the pollutants, Pollack Periodica, Vol, 6, No. 1, 2011, pp. 107-116.

[17] Horvát A., Buzás K. Comparison of roof runoff water originated from two types of roof material, Pollack Periodica, Vol. 7. No. 3, 2012, pp. 99-107.

[18] Rouvalis A., Karadima C., Zioris I. V., Sakkas V. A., Albanis T., Iliopoulou- Georgudaki J. Determination of pesticides and toxic potency of rainwater samples in western Greece, Ecotoxiology and Environment Safety, Vol. 72, No. 3, 2009, pp. 828-833.

[19] Melidis P., Akratos C. S., Tsihrintzis V., Trikilidou E. Characterization of rain and roof drainage water quality in Xanthi, Greece, Environmental Monitoring and Assessment, Vol. 127, No. 1-3, 2007, pp. 15-27.

[20] Ahmed W., Vieritz A., Goonetilleke A., Gardner T. Health risk from the use of roofharvested rainwater in Southeast Queensland, Australia, as potable or nonpotable water, determined using quantitative microbial risk assessment, Applied Environmental Microbiology, Vol. 76, No. 22, 2010, pp. 7382-7391.

[21] Hach Company, Device HQD portable meters, https://uk.hach.com/hqd-meters-intellicalprobes/hqd-portable-meters/family?productCategoryId=25114273672, (last visited: 4 . April 2020). 